\title{
TESTING AND ANALYSIS OF STUDENTS' CONCEPTION FROM PHYSICS
}

\section{Peter HOCKICKO - Gabriela TARJÁNYIOVÁ}

Abstract: This paper presents initial research results of using video analysis based tasks in the educational process of the students of the Faculty of Civil Engineering at the University of Žilina in Žilina. We represent the research methodology, the form of results' processing and their evaluation. In the end we report on the research results and the comparison of a control and the experimental group that has used the method of video analysis as well as of a group comprising of grammar school students.

Keywords: video analysis, Student's t-test, F-test, reliability, validity.

\section{TESTOVANIE A ANALÝZA FYZIKÁLNYCH PREDSTÁV}

Resumé: V príspevku prezentujeme prvé výsledky výskumu použitia videoanalýz vo vzdelávacom procese na vzorke študentov Stavebnej fakulty Žilinskej univerzity v Žiline. V príspevku je popísaná metodika výskumu, forma spracovania výsledkov a ich vyhodnotenie. V závere sú prezentované výsledky výskumu a ich porovnanie na kontrolnej a experimentálnej skupine, ktorá pracovala prostredníctvom videoanalýz a tiež aj na vzorke študentov gymnázií.

Kl'účové slová: videoanalýza, párový Studentov t-test, F-test, reliabilita, validita 


\section{1 Úvod}

Moderné interaktívne metódy s využitím učebných pomôcok vo forme multimediálneho DVD vo výuke (Krišták a kol., 2013a),b)), či projektové vyučovanie, kde sa na vyučovaní vo vzájomnej interakcii aktívne podiel'ajú učitel' i žiaci (Valovičová a kol., 2012), zvyšujú efektívnost' vyučovacieho procesu a pomáhajú vo vytváraní správneho obrazu o reálne fungujúcom svete. Mnohí pedagógovia a vedeckí pracovníci považujú za potrebné začat' $\mathrm{s}$ motiváciou $\mathrm{k}$ prírodovednému vzdelávaniu už $\mathrm{v}$ predprimárnom a primárnom vzdelávaní (Rochovská, 2012). Kým v predprimárnom vzdelávaní ide o osvojovanie základov prírodovednej gramotnosti, od primárneho vzdelávania sa táto kompetencia u žiakov už systematicky rozvíja (Kopáčová, 2012). Ak sa nerozvinú základy prírodovednej gramotnosti v tomto období, majú žiaci t'ažkosti pri riešení prírodovedných úloh na vyšších stupňoch škôl, prípadne vo vysokoškolskom štúdiu.

Množstvo výskumov dnes potvrdzuje, že študenti nedisponujú dostatočnou úrovňou prírodovednej gramotnosti. Medzinárodná štúdia PISA prezentuje, že úroveň prírodovednej gramotnosti slovenských žiakov na konci povinnej školskej dochádzky je podpriemerná (Rochovská, 2012).

Už naše predchádzajúce konferenčné výstupy a publikované prí- spevky poukázali na to, že predstava študentov o reálnych fyzikálnych dejoch nie je správna (Hockicko, Rochovská, 2013). Preto bola vytvorená sada videí, pomocou ktorej boli na prednáškach vysvetl'ované fyzikálne zákonitosti a $\mathrm{v}$ rámci výpočtových cvičení realizované videoanalýzy (Hockicko, 2013). Efektívnost' danej výukovej metódy sme sa rozhodli otestovat' prostredníctvom štandardných štatistických metód. Vytvorili sme test (v prílohe), ktorého obsahom boli otázky, na ktoré by študenti gymnázií (maturanti) a tiež aj študenti uchádzajúci sa o štúdium na vysokej škole mali vediet' odpovedat' (test bol pripravený z otázok starších ročníkov Monitoru). Daný test bol predložený študentom na vypracovanie na začiatku semestra a tiež aj na konci semestra. Študenti prvého ročníka Stavebnej fakulty Žilinskej univerzity v Žiline mali možnost' v priebehu letného semestra zúčastňovat' sa prednášok z fyziky, na ktorých boli preberané témy $\mathrm{z}$ mechaniky (kinematika, dynamika, tuhé teleso, kvapaliny, kmity), gravitačného pol'a, termiky a termodynamiky, pričom neboli explicitne preberané odpovede na testové otázky. Zároveň študenti navštevovali aj laboratórne a výpočtové cvičenia, pričom na výpočtových cvičeniach boli rozdelení do dvoch skupín - kontrolnej (riešila príklady štandardným spôsobom) a experimentálnej (príklady riešila 
prostredníctvom videoanalýz). Nasledujúca čast' ponúka štatistické spracovanie výsledkov.

\section{Analýza a vyhodnotenie testov}

Úvodný test (pre-test) sa uskutočnil na začiatku letného semestra 2013 a 2014. V roku 2013 ho absolvovalo 123 a v roku 2014121 študentov na úvodnom laboratórnom cvičení v priebehu 20-30 minút. Ten istý test na konci semestra (post-test) absolvovalo $109 \mathrm{v}$ roku 2013 a 100 študentov v roku 2014. Študenti absolvovali daný test s využitím počítača, pričom každý študent absolvoval rovnaký počet otázok, avšak poradie otázok ako aj poradie vo výbere $\mathrm{z}$ odpovedí bolo náhodne generované, aby sme zabránili odosielaniu si „správnych“ odpovedí. Následne boli výsledky testov uložené v databáze, odkial' boli po ukončení testovaní pripravené na d'alšie spracovanie. Prednášajúci sa hned' d'alší týždeň mohli oboznámit' s výsledkami pretestov, hlavne chybnými odpoved'ami a následne prispôsobit' prednášku tak, aby dokázali reagovat' na miskoncepcie.

Pre štatistické vyhodnotenie získaných dát bol použitý párový Studentov t-test, t.j. brali sme do úvahy len tých študentov, ktorí sa zúčastnili testovania aj na začiatku aj na konci semestra. Po spárovaní pre- a post-testov nám ostalo k dispozícii 155 vzoriek študentov. Už dané číslo nasvedčuje tomu, že v priebehu semestra dochádza k vel'kým fluktuáciám študentov, ved' vzhl'adom $\mathrm{k}$ počiatočnému stavu je to len $64 \% \mathrm{z}$ pôvodného počtu študentov. $Z$ toho sa dá usudzovat', že mnohí z tých, ktorí začali, nemajú seriózny záujem o úspešné ukončenie daného štúdia. Na druhej strane sa však niektorí študenti opakujúci ročník ,spamätajú“ až po $1 / 3$ semestra.

Hlavnou otázkou bolo, či študenti na konci semestra dosiahli nárast vedomostí a či daný nárast je štatisticky významný. Bola stanovená počiatočná hypotéza: $\mathrm{H}_{0}$ : priemerná úspešnost' na začiatku a na konci (pri d'alších hypotézach experimentálnej a kontrolnej skupiny) je rovnaká: $\mathrm{H}_{0}: \mu_{1}=\mu_{2}$ (verzus $\mathrm{H}_{1}: \mu_{1} \neq \mu_{2}$ ) (pričom rozdiel stredných hodnôt $\mu_{1}-\mu_{2}$ dvoch normálnych rozdelení $\mathrm{N}\left(\mu_{1}, \sigma_{1}{ }^{2}\right)$ a $\mathrm{N}\left(\mu_{2}\right.$, $\left.\sigma_{2}{ }^{2}\right)$ pre dve vyšetrované skupiny považujeme za rovnaký, blízky 0). $\mathrm{Na}$ overenie vyslovených hypotéz bol použitý test rozdielu aritmetických priemerov (dvojvýberový párový t-test na strednú hodnotu pre jednotlivé skupiny a dvojvýberový t-test pre porovnanie kontrolnej a experimentálnej skupiny), pričom sme testovali na hladine významnosti $\alpha=5 \%$ a predpokladali sme, že rozdiel stredných hodnôt $\mu_{1}$ - $\mu_{2}$ dvoch normálnych rozdelení $\mathrm{N}\left(\mu_{1}, \sigma_{1}{ }^{2}\right)$ a $\mathrm{N}\left(\mu_{2}, \sigma_{2}{ }^{2}\right)$ padne do $100 \cdot(1-\alpha) \%$ obojstranného intervalu spol'ahlivosti. Na začiatku testo- 
vania bola zist'ovaná zhoda medzi testovaným výberom a teoretickým rozdelením s predpokladom normálneho (Gauss) rozdelenia využitím jednovýberového neparametrického Kolmogorov - Smirnovho (K-S) testu, ktorá potvrdila normálnost' vyšetrovaných rozdelení (vypočítané parametre boli nižšie ako kritické hodnoty pre K-S test normality na hladine významnosti $\alpha=$ $5 \%$, ktoré boli určené pre vyšetrované rozdelenia využitím programu Statistica $\left.\left(D<D_{\max , \alpha}\right)\right)$.

Ako ukazuje tabul'ka 1, na konci semestra $\mathrm{v}$ post-teste bola priemerná úspešnost' študentov približne $33 \%$, pričom v pre-teste realizovanom na začiatku semestra bola $23 \%$.

\begin{tabular}{|l|l|l|}
\hline \multicolumn{3}{|l|}{$\mathrm{t}$-Test: Paired Two Sample for Means } \\
\hline & $\begin{array}{l}\text { post- } \\
\text { test }\end{array}$ & pre-test \\
\hline Mean & 33.03 & 22.81 \\
\hline Variance & 235.23 & 100.68 \\
\hline Observations & 155 & 155 \\
\hline Pearson Correlation & 0.33 & \\
\hline $\mathrm{df}$ & 154 & \\
\hline $\mathrm{t}$ Stat & 8.31 & \\
\hline $\mathrm{P}(\mathrm{T} \leq \mathrm{t})$ one-tail & $2.36 \mathrm{E}-$ & \\
& 14 & \\
\hline $\mathrm{t}$ Critical one-tail & 1.65 & \\
\hline $\mathrm{P}(\mathrm{T} \leq \mathrm{t})$ two-tail & $4.72 \mathrm{E}-$ & \\
& 14 & \\
\hline $\mathrm{t}$ Critical two-tail & 1.98 & \\
\hline
\end{tabular}

Tab. 1: Párový test (všetci študenti).

Ked’že vypočítaný parameter $|t|>$ $t_{\text {critical(two-tail) }}$ pre obojstranný inter- val spol'ahlivosti, hypotéza $\mathrm{H}_{0}: \mu_{1}=$ $\mu_{2}$ bola zamietnutá a bola teda potvrdená hypotéza $\mathrm{H}_{1}: \mu_{1} \neq \mu_{2}$. Na základe toho sme zvolili novú hypotézu: $\mathrm{H}_{0}: \mu_{1}>\mu_{2}$ (pre $100 \cdot(1-\alpha)$ $\%$ pravostranný interval spol'ahlivosti pre rozdiel $\mu_{2}-\mu_{1}$. Ked'že $t \in$ $\left.<t_{\text {critical(one-tail) }}, \infty\right)$, hypotéza $\mathrm{H}_{0}: \mu_{1}$ $>\mu_{2}$ bola potvrdená. Štatistické testovanie využitím párového Studentovho t-testu potvrdilo štatisticky významný rozdiel vo vedomostiach na konci a začiatku semestra.

V d'alšej časti testovania sme sa zamerali na jednotlivé skupiny experimentálnu a kontrolnú a sledovali nárast vedomostí $\mathrm{v}$ samostatných skupinách (Tab. 2 a 3). Aj $\mathrm{v}$ prípade samotných skupín bol potvrdený štatisticky významný rozdiel vo vedomostiach na konci a začiatku semestra. 


\begin{tabular}{|l|l|l|}
\hline \multicolumn{3}{|l|}{ t-Test: Paired Two Sample for Means } \\
\hline $\begin{array}{l}\text { Experimental } \\
\text { group }\end{array}$ & Pre-test & $\begin{array}{l}\text { Post- } \\
\text { test }\end{array}$ \\
\hline Mean & 38.29 & 23.68 \\
\hline Variance & 267.94 & 111.74 \\
\hline Observations & 38 & 38 \\
\hline $\begin{array}{l}\text { Pearson Correlati- } \\
\text { on }\end{array}$ & 0.21 & \\
\hline df & 37 & \\
\hline t Stat & 5.12 & \\
\hline P(T $\leq \mathrm{t})$ one-tail & $4.79 \mathrm{E}-$ & \\
\hline t Critical one-tail & 1.69 & \\
\hline P(T $\leq \mathrm{t})$ two-tail & $9.58 \mathrm{E}-$ & \\
\hline t Critical two-tail & 2.03 & \\
\hline
\end{tabular}

Tab. 2: Párový test (experimentálna skupina).

\begin{tabular}{|l|l|l|}
\hline \multicolumn{3}{|l|}{$\mathrm{t}$-Test: Paired Two Sample for Means } \\
\hline Control group & Pre-test & $\begin{array}{l}\text { Post- } \\
\text { test }\end{array}$ \\
\hline Mean & 31.32 & 22.52 \\
\hline Variance & 214.82 & 97.68 \\
\hline Observations & 117 & 117 \\
\hline $\begin{array}{l}\text { Pearson Correlati- } \\
\text { on }\end{array}$ & 0.37 & \\
\hline df & 116 & \\
\hline $\mathrm{t}$ Stat & 6.65 & \\
\hline P(T $\leq \mathrm{t})$ one-tail & $5.03 \mathrm{E}-$ & \\
\hline $\mathrm{t}$ Critical one-tail & 10 & \\
\hline $\mathrm{P}(\mathrm{T} \leq \mathrm{t})$ two-tail & $\begin{array}{l}1.66 \\
09\end{array}$ & \\
\hline $\mathrm{t}$ Critical two-tail & 1.98 & \\
\hline
\end{tabular}

Tab. 3: Párový test (kontrolná skupina).

Správnost' rozhodnutia o prijatí alternatívnej hypotézy o nerovnosti stredných hodnôt nám potvrdzuje i P-hodnota $(\mathrm{P}(\mathrm{T} \leq \mathrm{t}))$, ktorá je výrazne menšia ako zvolená hladina významnosti $\alpha=0,05$ ( $\mathrm{P}<$ 0,001).

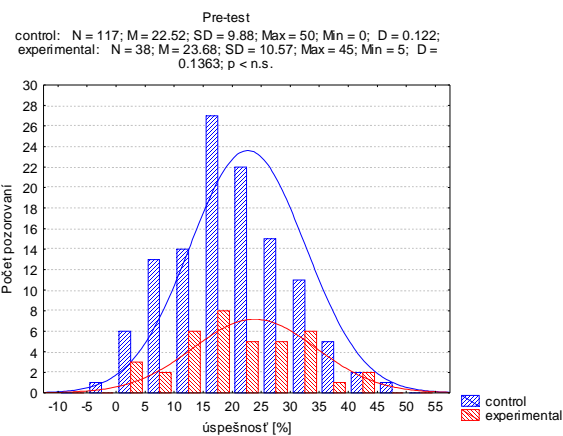

Obr. 1: Pre-test kontrolná a experimentálna skupina.

Ďalej sa naša pozornost' sústredila na to, či je štatisticky významný rozdiel medzi vedomost'ami pri experimentálnej a kontrolnej skupine na začiatku a konci semestra. Skôr, ako bolo možné začat' testovanie hypotézy $\mathrm{H}_{0}: \mu_{1}=\mu_{2}$, bolo potrebné použit' F-test (Fisher-Snedecor test) rovnosti rozptylov dvoch normálnych populácií $\left(\mathrm{H}_{0}: \sigma_{1}^{2}=\sigma_{2}^{2}\right.$ verzus $\left.H_{1:} \sigma_{1}^{2} \neq \sigma_{2}^{2}\right)$. Po stanovení rovnosti (prípadne nerovnosti) rozptylov bol pre testovanie hypotézy $\mathrm{H}_{0}: \mu_{1}=\mu_{2}$ použitý dvojvýberový Studentov t-test pre nerovnaké vel'kosti skupín s rovnakými (prípadne rôznymi) rozptylmi. Ked'že vypočítaný parameter $F$ spíńa podmienku: $F_{\text {critical }_{1-\alpha / 2}}<F<$ 
$F_{\text {critical }_{\alpha / 2}}$ (obojstranný interval $F$ leží v rozmedzí $(0,567$ - 1,638)), predpokladaná hypotéza rovnosti rozptylov pre experimentálnu a kontrolnú skupinu na začiatku semestra $\mathrm{H}_{0}: \sigma_{1}{ }^{2}=\sigma_{2}{ }^{2}$ bola potvrdená.

\begin{tabular}{|l|l|l|}
\hline \multicolumn{3}{|l|}{ F-Test Two-Sample for Variances } \\
\hline Pre-test & $\begin{array}{l}\text { experimen- } \\
\text { tal }\end{array}$ & control \\
\hline Mean & 23.68421 & $\begin{array}{l}22.5213 \\
7\end{array}$ \\
\hline Variance & 111.7354 & $\begin{array}{l}97.6827 \\
3\end{array}$ \\
\hline Observations & 38 & 117 \\
\hline df & 37 & 116 \\
\hline F & 1.143861 & \\
\hline P(F $\leq$ f) one-tail & 0.290043 & \\
\hline $\begin{array}{l}\text { F Critical one- } \\
\text { tail }\end{array}$ & 1.513534 & \\
\hline
\end{tabular}

Tab. 4: F-test (pre-test).

Následne bol pre testovanie hypotézy $\mathrm{H}_{0}: \mu_{1}=\mu_{2}$ použitý dvojvýberový Studentov t-test pre nerovnaké vel'kosti skupín s rovnakými rozptylmi, ktorý potvrdil hypotézu o rovnosti vstupnej vedomostnej úrovni experimentálnej aj kontrolnej skupiny na začiatku semestra $\left(|t|<t_{\text {criticalltwo-tail })}\right.$ (Tab. 5).

\begin{tabular}{|l|l|l|}
\hline \multicolumn{3}{|l|}{$\begin{array}{l}\text { t-Test: Two-Sample Assuming Equal } \\
\text { Variances }\end{array}$} \\
\hline Pre-test & $\begin{array}{l}\text { Experi- } \\
\text { mental }\end{array}$ & $\begin{array}{l}\text { Con- } \\
\text { trol }\end{array}$ \\
\hline Mean & 23.68 & 22.52 \\
\hline Variance & 111.74 & 97.68 \\
\hline Observations & 38 & 117 \\
\hline $\begin{array}{l}\text { Pooled Vari- } \\
\text { ance }\end{array}$ & 101.08 & \\
\hline $\mathrm{df}$ & 153 & \\
\hline $\mathrm{t}$ Stat one- & 0.619448 & \\
\hline $\begin{array}{l}\mathrm{P}(\mathrm{T} \leq \mathrm{t}) \\
\text { tail }\end{array}$ & 0.271 & \\
\hline $\begin{array}{l}\mathrm{t} \text { Critical one- } \\
\text { tail }\end{array}$ & 1.654874 & \\
\hline $\begin{array}{l}\mathrm{P}(\mathrm{T} \leq \mathrm{t}) \quad \text { two- } \\
\text { tail }\end{array}$ & 0.536542 & \\
\hline $\begin{array}{l}\mathrm{t} \text { Critical two- } \\
\text { tail }\end{array}$ & 1.97559 & \\
\hline
\end{tabular}

Tab. 5: t-test $s$ predpokladom rovností rozptylov vyšetrovaných skupín (pre-test).

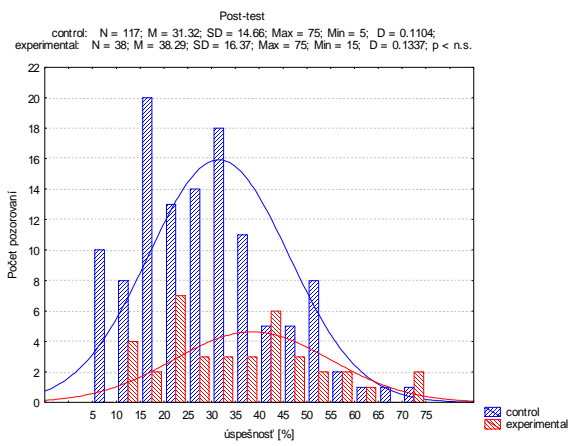

Obr. 2: Post-test kontrolná a experimentálna skupina.

Obdobná analýza ako v predchádzajúcom prípade bola urobená aj na konci semestra. $F$-test potvrdil rovnost' rozptylov dvoch normál- 
nych populácií na konci semestra (Tab. 6) $\left(\mathrm{H}_{0}: \sigma_{1}^{2}=\sigma_{2}^{2}\right)$.

\begin{tabular}{|l|l|l|}
\hline F-Test Two-Sample for Variances \\
\hline Post-test & $\begin{array}{l}\text { Experi- } \\
\text { mental }\end{array}$ & Control \\
\hline Mean & 38.28947 & $\begin{array}{l}31.3247 \\
9\end{array}$ \\
\hline Variance & 267.941 & $\begin{array}{l}214.824 \\
6\end{array}$ \\
\hline Observations & 38 & 117 \\
\hline df & 37 & 116 \\
\hline F & 1.247254 & \\
\hline P(F $\leq$ f) one-tail & 0.187889 & \\
\hline $\begin{array}{l}\text { F Critical one- } \\
\text { tail }\end{array}$ & 1.513534 & \\
\hline
\end{tabular}

Tab. 6: F-test (post-test).

\begin{tabular}{|l|l|l|}
\hline \multicolumn{3}{|l|}{$\begin{array}{l}\text { t-Test: Two-Sample Assuming Equal } \\
\text { Variances }\end{array}$} \\
\hline Post-test & $\begin{array}{l}\text { Experimen- } \\
\text { tal }\end{array}$ & $\begin{array}{l}\text { Con- } \\
\text { trol }\end{array}$ \\
\hline Mean & 38.29 & 31.32 \\
\hline Variance & 267.94 & 214.82 \\
\hline Observations & 38 & 117 \\
\hline $\begin{array}{l}\text { Pooled Varian- } \\
\text { ce }\end{array}$ & 227.67 & \\
\hline $\mathrm{df}$ & 153 & \\
\hline $\mathrm{t}$ Stat & 2.47211 & \\
\hline $\mathrm{P}(\mathrm{T} \leq \mathrm{t})$ one-tail & 0.007264 & \\
\hline $\begin{array}{l}\mathrm{t} \text { Critical one- } \\
\text { tail }\end{array}$ & 1.654874 & \\
\hline $\mathrm{P}(\mathrm{T} \leq \mathrm{t})$ two-tail & 0.014527 & \\
\hline $\begin{array}{l}\mathrm{t} \text { Critical two- } \\
\text { tail }\end{array}$ & 1.97559 & \\
\hline
\end{tabular}

Tab. 7: t-test s predpokladom rovností rozptylov vyšetrovaných skupín.

Ďalej bol pre testovanie hypotézy $\mathrm{H}_{0}: \mu_{1}=\mu_{2}$ použitý dvojvýbero- vý Studentov t-test pre nerovnaké vel'kosti skupín s rovnakými rozptylmi. Na základe výsledkov $\left(|t|>t_{\text {critical(two-tail })}\right)$ však nulovú hypotézu o rovnosti výstupnej vedomostnej úrovni skupín zamietame na každej hladine významnosti väčšej ako $1,4 \%$. Preto bola hypotéza $\mathrm{H}_{0}: \mu_{1}=\mu_{2}$ zamietnutá a bola prijatá nová hypotéza $\mathrm{H}_{0}: \mu_{1} \neq \mu_{2}$ pre $100 \cdot(1-\alpha) \%$ l'avostranný interval spol'ahlivosti pre rozdiel $\mu_{1}-\mu_{2}$. Ked'že $t \in\left\langle t_{\text {critical(one-tail), }} \infty\right)$, hypotéza $\mathrm{H}_{0}: \mu_{1}>\mu_{2}$ bola potvrdená. Štatistické testovanie využitím Studentovho t-testu potvrdilo štatisticky významný rozdiel vo vedomostiach experimentálnej a kontrolnej skupiny na konci výučby.

Daný test sme v spolupráci s učitel'mi gymnázií použili aj pri testovaní študentov gymnázií). Obrázok 3 ukazuje výsledky gymnazistov. Ich priemerná úspešnost' bola $46 \%$, čo je viac, ako percentuálna úspešnost' experimentálnej skupiny študentov na univerzite. $\mathrm{Na}$ druhej strane je však potrebné upozornit' na najpočetnejšiu skupinu študentov $\mathrm{v}$ intervale úspešnosti 15-20 \%. Ak si uvedomíme, že vstupná úroveň vedomostí experimentálnej aj kontrolnej skupiny bola na úrovni $22 \%$, možno predpokladat', že na technické univerzity prichádzajú z gymnázií práve žiaci $s$ najnižšími znalost'ami z fyziky. Dané tvrdenie by bolo 
vhodné ešte potvrdit' na väčšej testovanej vzorke.

gymnázium: $\mathrm{N}=62 ; \mathrm{M}=46.0484 ; \mathrm{SD}=19.4417 ; \mathrm{Max}=85 ; \mathrm{Min}=15 ; \mathrm{D}=$ $0.0873 ;$ p $<$ n.s.; Lil $<1$

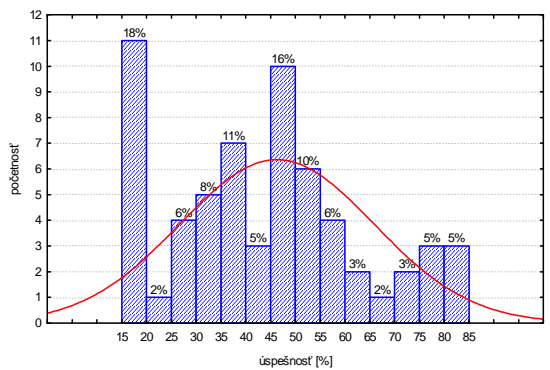

Obr. 3: Pre-test gymnazisti.

\section{Spol'ahlivost' testu, validita a reliabilita}

Počas testovania boli určené aj základné vlastnosti didaktického testu reliabilita, obtiažnost' úloh a validita testu. Reliabilita, resp. spol'ahlivost', presnost' didaktického testu je $\mathrm{v}$ našom prípade vyjadrená koeficientom, ktorého vel'kost' je udávaná $\mathrm{v}$ rozsahu od 0 po 1 , pričom hodnota 0 označuje nulovú a hodnota 1 označuje maximálnu reliabilitu. Vzhl'adom na to, že je dodržaná podmienka na obsahovú homogenitu testových úloh, sme ako vhodnú metódu na výpočet koeficientu reliability volili Kuderov - Richardsonov vzorec v nasledujúcom tvare (Jeřábek, 2010):

$$
r_{\mathrm{KR} 20}=\frac{k}{k-1}\left(1-\frac{\sum_{i=1}^{k} p_{i} q_{i}}{s^{2}}\right)
$$

kde $k$ je počet úloh testu, $p$ je relatívny počet študentov, ktorí riešili danú úlohu správne, $q$ je relatívny počet študentov, ktorí riešili danú úlohu nesprávne a $s$ je smerodajná odchýlka pre celkové výsledky študentov v teste.

Bola vypočítaná reliabilita testu, pre skupinu študentov $\mathrm{SvF}$ a študentov vybraných gymnázií. Koeficient reliability testu robeného pre 1. ročník SvF na začiatku semestra v šk. roku 2012/2013 bol 0,13, na konci semestra 0,58; v šk. roku 2013/2014 na začiatku semestra bol 0,43 , na konci semestra 0,67 . U študentov gymnázií bola hodnota 0,76 , čo je nad doporučovanou hodnotou reliability, a teda test je dostatočne spol'ahlivý a presný. Pri testoch s menším počtom otázok je odporúčaná minimálna hodnota koeficientu aspoň 0,6 , takže možno konštatovat', že test robený na konci semestra je spol'ahlivý, a možno ho považovat' za dobrý nástroj overenia vedomostí študentov.

Z hl'adiska určenia kvality didaktického testu sme určovali obtiažnost' úloh. Obtiažnost' charakterizuje čast' celkového počtu študentov, ktorí riešili správne, alebo naopak čast' študentov, ktorí riešili úlohu nesprávne (možno ju vyjadrit' aj percentuálne). Pri určovaní sme vypočítali index obtiažnosti $P$, podl'a vzt'ahu: $P=$ $\left(n_{n} / n\right) \cdot 100$, kde $n_{n}$ je počet študentov, ktorí riešili úlohu správne, $n$ je celkový počet študentov riešiacich 
test. Úlohy s indexom menším ako 20 sú privel'mi náročné a väčším ako 80 sú privel'mi jednoduché, najvhodnejšie sú úlohy s hodnotou okolo 50.

Ako si možno všimnút' (Tab. 8), niektoré úlohy ukazujú na extrémne hodnoty $P$. Po hlbšom skúmaní bolo zistené, že extrémne hodnoty u niektorých úloh sú spôsobené tým, že testovaná oblast' nebola zaradená do vyučovacieho procesu na SvF pre všetky testované skupiny žiakov $v$ rovnakom rozsahu a taktiež mnohí zo študentov nenavštevovali prednášky pravidelne.

\begin{tabular}{|c|c|c|c|c|c|c|c|c|c|c|}
\hline \multirow{2}{*}{$\begin{array}{c}\text { Č.ú } \\
\text {. }\end{array}$} & \multirow[b]{2}{*}{ Gym } & \multicolumn{2}{|c|}{$2012 / 2013$} & \multicolumn{2}{|c|}{$2013 / 2014$} & \multirow[b]{2}{*}{$\begin{array}{c}\text { Gy } \\
\mathrm{m}\end{array}$} & \multicolumn{2}{|c|}{ 2012/2013 } & \multicolumn{2}{|c|}{$2013 / 2014$} \\
\hline & & $\begin{array}{c}\text { SvF- } \\
\text { pre }\end{array}$ & $\begin{array}{c}\text { SvF- } \\
\text { po }\end{array}$ & $\begin{array}{c}\text { SvF- } \\
\text { pre }\end{array}$ & $\begin{array}{c}\text { SvF- } \\
\text { po }\end{array}$ & & $\begin{array}{c}\text { SvF- } \\
\text { pre }\end{array}$ & $\begin{array}{c}\text { SvF- } \\
\text { po }\end{array}$ & $\begin{array}{c}\text { SvF- } \\
\text { pre }\end{array}$ & $\begin{array}{c}\text { SvF- } \\
\text { po }\end{array}$ \\
\hline & $\mathrm{P}$ & $\mathrm{P}$ & $\mathrm{P}$ & $\mathrm{P}$ & $\mathrm{P}$ & $\mathrm{r}_{\mathrm{bk}}$ & $\mathrm{r}_{\mathrm{bk}}$ & $\mathrm{r}_{\mathrm{bk}}$ & $\mathrm{r}_{\mathrm{bk}}$ & $\mathrm{r}_{\mathrm{bk}}$ \\
\hline 1 & 66,1 & 13,8 & 29,4 & 24,3 & 30 & 0,7 & 0,3 & 0,5 & 0,6 & 0,4 \\
\hline 2 & 85,5 & 24,4 & 49,5 & 40,9 & 50 & 0,4 & 0,4 & 0,6 & 0,7 & 0,7 \\
\hline 3 & 56,5 & 30,9 & 22 & 18,2 & 23 & 0,7 & 0,4 & 0,5 & 0,2 & 0,5 \\
\hline 4 & 70,9 & 39 & 45,9 & 37,9 & 39 & 0,6 & 0,2 & 0,3 & 0,5 & 0,4 \\
\hline 5 & 45,2 & 6,5 & 32,1 & 26,5 & 26 & 0,3 & 0,4 & 0,3 & 0,7 & 0,3 \\
\hline 6 & 20,9 & 14,6 & 36,7 & 30,3 & 30 & 0,6 & 0,2 & 0,5 & 0,3 & 0,4 \\
\hline 7 & 37,1 & 25,2 & 31,2 & 25,8 & 38 & 0,7 & 0,5 & 0,4 & 0,4 & 0,5 \\
\hline 8 & 50 & 12,2 & 29,4 & 24,3 & 38 & 0,8 & 0,3 & 0,5 & 0,5 & 0,7 \\
\hline 9 & 58,1 & 11,4 & 29,4 & 24,3 & 26 & 0,6 & 0,3 & 0,3 & 0,1 & $-0,1$ \\
\hline 10 & 54,8 & 19,5 & 44 & 36,4 & 44 & 0,5 & 0,3 & 0,6 & 0,4 & 0,7 \\
\hline 11 & 29 & 4,9 & 31,2 & 25,8 & 27 & 0,6 & 0,6 & 0,5 & 0,8 & 0,6 \\
\hline 12 & 35,5 & 5,7 & 18,3 & 15,1 & 21 & 0,8 & 0,4 & 0,6 & 0,4 & 0,6 \\
\hline 13 & 24,2 & 13 & 28,4 & 23,5 & 40 & 0,2 & 0,4 & 0,5 & 0,1 & 0,5 \\
\hline 14 & 75,8 & 43,9 & 68,8 & 56,9 & 84 & 0,3 & 0,3 & 0,3 & 0,3 & 0,3 \\
\hline 15 & 59,7 & 25,2 & 13,8 & 11,4 & 18 & 0,6 & 0,2 & 0,4 & 0,4 & 0,4 \\
\hline 16 & 27,4 & 17,9 & 38,5 & 31,8 & 37 & 0,2 & 0,2 & 0,5 & 0,5 & 0,4 \\
\hline 17 & 22,6 & 4,1 & 7,3 & 6 & 17 & 0,8 & 0,2 & 0,6 & 0,5 & 0,7 \\
\hline 18 & 24,2 & 4,9 & 6,4 & 5,3 & 17 & 0,6 & 0,6 & 0,03 & 0,3 & 0,5 \\
\hline 19 & 74,2 & 6,5 & 21,1 & 17,4 & 20 & 0,5 & 0,4 & 0,5 & 0,7 & 0,6 \\
\hline 20 & 30,6 & 17,9 & 26,6 & 21,9 & 40 & 0,5 & 0,4 & 0,3 & 0,4 & 0,5 \\
\hline
\end{tabular}

Tab. 8: Index obtiažnosti a koeficient biseriálnej korelácie jednotlivých úloh testu. 
Pri d'alšom použití testu je potrebné zvážit' vyradenie úloh alebo ich upravenie, ako napríklad usporiadanie úloh podla narastajúcej obtiažnosti, ktorá pri našom časovo obmedzenom teste môže vytvorit' lepšie podmienky pre slabších študentov.

Validita charakterizuje platnost' testu a vyjadruje to, či test, respektíve jednotlivé úlohy preverujú tie vedomosti, ktoré majú byt' skutočne preverené. Obsahová validita sa spravidla sleduje a skúma v didaktickom teste, ktorého obsah tvoria $\mathrm{v}$ dostatočnej miere úlohy tej časti učiva, ktoré chceme preverovat'. Na určenie validity testu sa používa často koeficient korelácie r, ktorý určuje štatisticky významnú závislost' medzi skúmanými javmi. Niektorí autori uvádzajú minimálnu hodnotu koeficientu korelácie 0,3. $\mathrm{Na}$ určenie obsahovej validity, sme použili koeficient biseriálnej korelácie $r_{b k}$, ktorý je považovaný za vhodný nástroj pre určenie obsahovej validity jednotlivých otázok didaktického testu (Chráska, 2007).

\section{Vzt'ah medzi úspešnost'ou štu- dentov $v$ danej úlohe a celkovými výsledkami $v$ teste}

Obsahová validita úloh v postteste sa pohybuje do maximálnych hodnôt 0,6 čo je stredná hodnota koeficientu korelácie. O úlohe, ktorá dosahuje koeficient korelácie 0,62 možno povedat', že má strednú obsahovú validitu a dokáže prie- merne rozlíšit' študentov podl'a ich vedomostí. Minimum koeficientu korelácie je okolo $\pm 0,1$; v jednej otázke (č. 18) bola dokonca hodnota 0,03 , čo naznačuje vel'mi nízku obsahovú validitu danej úlohy. $\mathrm{Z}$ toho možno usúdit', že daná úloha nie je vhodná na posúdenie vedomostí študentov z danej oblasti. Je predpoklad, že študenti odpovede danej úlohy len „natipovali“. $\mathrm{V}$ pre-teste bolo maximum 0,61 a viac otázok s hodnotami okolo 0,2 .

Tučným písmom zapísané hodnoty indexu obtiažnosti $P$ otázky poukazujú na vel'mi t’ažké otázky (iba u študentov SvF!). Avšak, to že otázka je náročná, nebolo potvrdené u gymnazistov a teda dané testové otázky sú vhodné na posúdenie vedomostí študentov na úrovni gymnázia. Čo sa týka študentov SvF, nízke hodnoty v postteste boli spôsobené tým, že niektoré témy súvisiace s otázkou neboli odprednášané a precvičené v dostatočnej miere (koniec semestra, posledné prednášky odpadli v dôsledku štátnych sviatkov). U všetkých ostatných otázok je index obtiažnosti v intervale 10-90, a teda test môžeme považovat' za spol'ahlivý.

Pri úlohe číslo 13 vyšla u gymnazistov obsahová validita otázky nižšia $v$ porovnaní so študentami na SvF (2012/2013), čo nasvedčuje, že daná otázka nie je vhodná pre študentov gymnázií. Tento záver po- 
tvrdili aj naše rozhovory s učitel'mi gymnázií, ktorí sa vyjadrili, že oblast', do ktorej spadá daná testová otázka nebola na niektorých gymnáziách preberaná.

Množstvo výskumov dnes potvrdzuje, že študenti nedisponujú dostatočnou úrovňou prírodovednej gramotnosti. Medzinárodná štúdia PISA prezentuje, že úroveň prírodovednej gramotnosti slovenských žiakov na konci povinnej školskej dochádzky je podpriemerná (Rochovská, 2012). Je preto potrebné začat' $s$ formovaním fyzikálnych predstáv už skôr ako na vysokej škole a v dostatočnej miere.

\section{Analýza predstáv študentov}

Odpovede na úlohy v teste sú zapísané tak, že správne odpovede sú tie patriace $\mathrm{k}$ písmenku $\mathrm{A}$, vid' príloha.

Hoci počas semestra u študentov SvF nastal nárast vedomostí (úloha 1: zo $17 \%$ na $36 \%$ správnych odpovedí), stále vysoké percento študentov má mylné vedomosti o zrýchlených pohyboch. Z výsledkov odpovedí na úlohu č. 1 aj č. 2 (Obr. 4, 5) nadobúdame dojem, že študenti jednoducho neakceptujú iný vzt'ah pre definíciu rýchlosti ako je definícia rýchlosti pre rovnomerný pohyb, ktorý majú zafixovaný zo strednej školy, pričom zo zadania úlohy je zrejmé, že ide o pohyb zrýchlený.

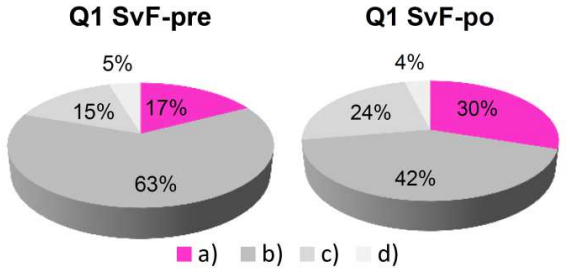

Obr. 4: Výsledky odpovedí na úlohu č. 1

Odpovede na úlohy č., 2, 3, 15 a 19 signalizujú vel'mi dôležitý fakt, že študenti majú problémy s grafickými závislost’ami. Jednoducho povedané nevedia čítat' z grafu. Pri úlohe č. 15 je podiel odpovedí študentov približne rovnaký, z čoho možno predpokladat', že študenti dokonca iba tipovali odpovede.

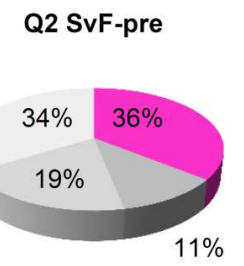

Q2 SvF-po
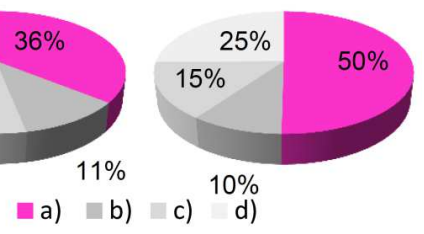

Obr. 5: Výsledky odpovedí na úlohu č. 2

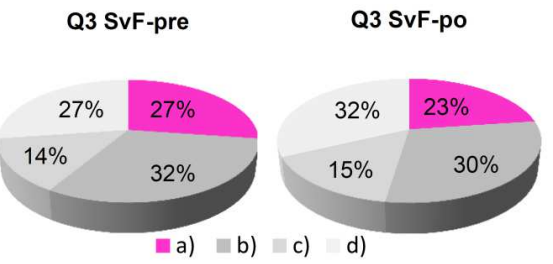

Obr. 6: Výsledky odpovedí na úlohu č. 3 
$\mathrm{Na}$ obr. 7 vidiet', že študenti gymnázií sa ovel'a lepšie orientujú $\mathrm{v}$ problematike trenia ako študenti študujúci na univerzite. Za vel'mi zlé pokladáme však fakt, že hoci nastalo zlepšenie, ako vidiet' v porovnavácích grafoch na začiatku semestra odpovedalo správne $19 \%$, na konci $34 \%$ študentov, až $76 \%$ odpovedí bolo nesprávnych. A teda aj po absolvovaní základného kurzu fyziky sú ich predstavy o súvisiacich javoch mylné. Zvlášt' sa možno pri analýzach sústredit' na odpoved' $d$, ktorú si vybralo na začiatku semestra viac ako polovica študentov a na konci semestra takmer polovica študentov.

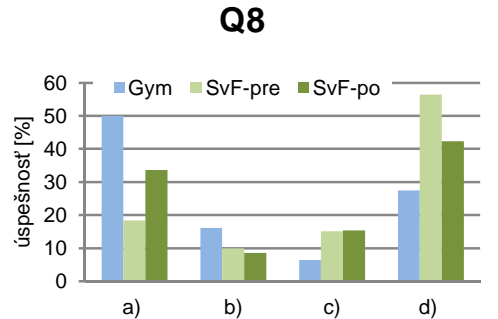

Q8 SvF-pre

Q8 SvF-po

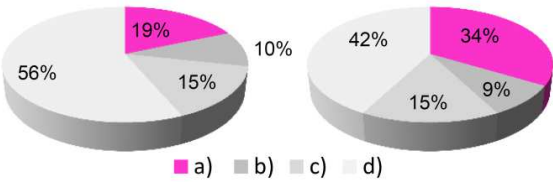

Obr. 7: Výsledky odpovedí na úlohu č. 8

Ako možno vidiet' na obrázku 8,9 z výsledkov testovania je zrejmé, že v oblasti dynamiky kvapalín majú gymnazisti aj naši študenti nedostatočné znalosti. U študentov nastalo celkové zlepšenie po semestri, ale ako vidiet' celkovo $70 \%$ (Q.11) a 80 \% (Q.12) študentov má stále zlé predstavy. Väčšina študentov síce pri otázke 11 uviedla, že sa pri rozšírení trubice rýchlost' pretekajúcej kvapaliny zníži, avšak väčšina študentov nedokázala správne aplikovat' rovnicu spojitosti. Obdobne tomu bolo pri otázke 12 , kde viac ako $2 / 3$ študentov nevie aplikovat' Bernoulliho rovnicu (a to aj na konci semestra, dokonca aj pri skúške).

\section{Q11}
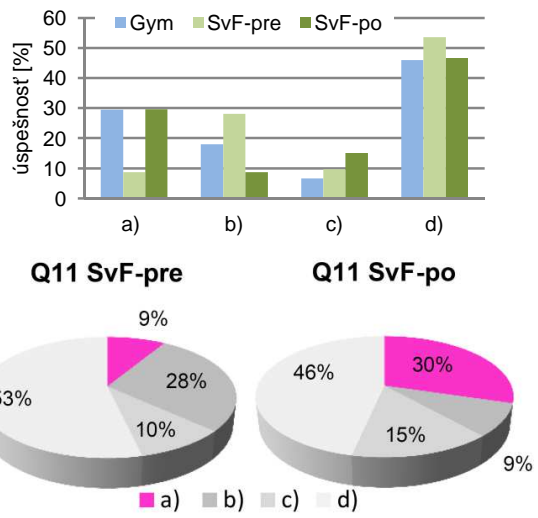

Obr. 8: Výsledky odpovedí na úlohu č. 11 


\section{Q12}

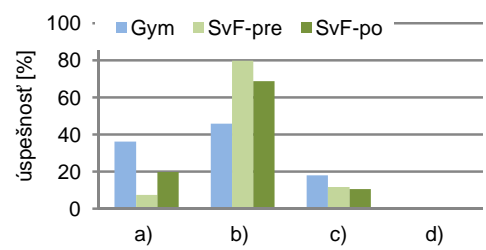

Q12 SvF-pre

$12 \% \quad 1 \% \quad 7 \%$

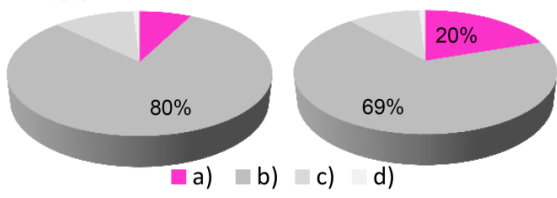

Obr. 9: Výsledky odpovedí na úlohu č. 12

Dost' zarážajúce sú výsledky z úlohy č. 13., nakol'ko úloha súvisí s praxou, kde viac ako $65 \%$ študentov $\mathrm{SvF}$ volilo odpoved' $c$ na začiatku semestra a takmer $50 \%$ na konci semestra.

Q13

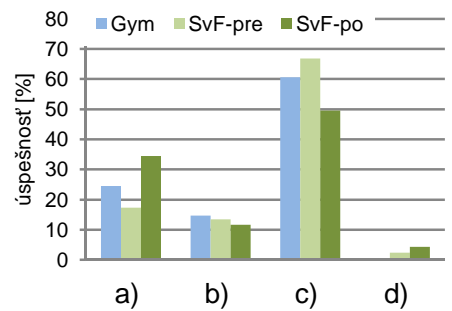

Obr. 10: Výsledky odpovedí na úlohu č. 13

Študenti gymnázií aj študenti univerzity majú zlé predstavy o dejoch v plynoch (obr. 11) a taktiež o kmi- tavých pohyboch (obr. 12, 13). Všimnime si, aké vysoké percento študentov $\mathrm{SvF}$ volilo odpovede $b, c$ aj na začiatku aj konci semestra.

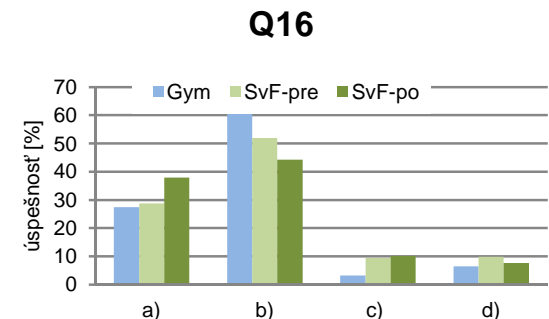

Obr. 11: Výsledky odpovedí na úlohu č. 16

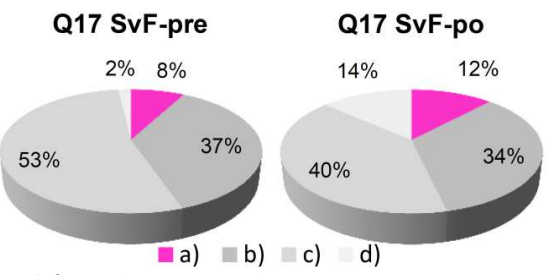

Obr. 12: Výsledky odpovedí na úlohu č. 17

\section{Q18}

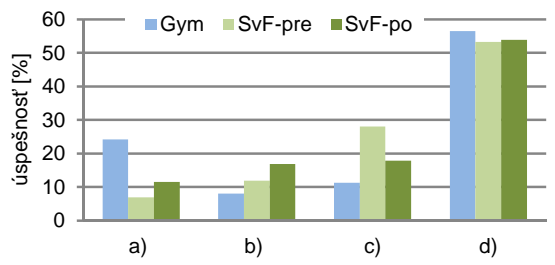

Obr. 13: Výsledky odpovedína úlohu č. 18

Pri bližšom skúmaní odpovedí študentov na úlohu č. 20 sme prišli na to, že študenti zabúdajú premieňat' jednotky. Žial' to nie je nič prekvapivé, zo skúsenosti vieme, že 
študenti jednotkám fyzikálnych veličín nepripisujú dôležitý význam.

\section{Záver}

Nami realizované testovanie ukázalo:

- Na konci semestra nastal nárast vedomostí u experimentálnej aj u kontrolnej skupiny.

- U experimentálnej skupiny, ktorá realizovala výpočtové cvičenia prostredníctvom videoanalýz bol nárast vedomostí vyšší.

- Rozdiel vo vedomostnej úrovni medzi experimentálnou a kontrolnou skupinou bol štatisticky významný na hladine významnosti $\alpha=5 \%$.

- Avšak vedomostná úroveň študentov gymnázií bola vyššia ako študentov SvF po skončení semestra!

- Koeficient reliability testu dosahoval hodnoty $0.58-0.75$ na základe čoho možno považovat' daný test za spol'ahlivý.

- Ďalšia analýza úloh poukázala na to, že aj ked' na konci semestra dôjde $\mathrm{k}$ zvýšeniu počtu správnych odpovedí, nad'alej ostáva vel'ká skupina študentov, ktorých predstava o fyzikálnych dejoch je spojená s chybnými predstavami, tzv. miskoncepciami.

- Využitie videoanalýz a simulácií dejov vo vyučovacom procese je jednou z možností, ako možno zlepšovat' názornost' a budovat' správne fyzikálne predstavy o dejoch okolo nás.

\section{Pod'akovanie}

Táto práca bola podporovaná Slovenskou grantovou agentúrou KEGA na základe zmluvy č. 035ŽU-4/2012. Autori taktiež d'akujú učitel'om fyziky na gymnáziách: Bilingválne gymnázium Žilina (Mgr. Marek Matuška), Gymnázium Varšavská Žilina (Mgr. Jozefína Špániová) a Gymnázium v Ružomberku (Mgr. Miroslav Krajník) za ich spoluprácu pri testovaní žiakov gymnázií.

\section{Literatúra}

[1] HOCKICKO, P. a ROCHOVSKÁ, I. Hl'adanie, analýza a možnosti odstraňovania chybných predstáv vo fyzikálnom vzdelávaní na technických univerzitách. Zborník príspevkov z konferencie Tvorivý učitel' fyziky VI, Národný festival fyziky 2013, 1. vyd, Bratislava, Slovenská fyzikálna spoločnost', 2013, s. 126-132. ISBN 978-80971450-0-2.

[2] HOCKICKO, P. Fyzika v príkladoch a videopríkladoch / Videoanalysis based tasks in physics,. 1.vyd. Žilina, Edis, [DVD] 2013. ISBN 978-80-554-0811-8 Dostupné na:

http://hockicko.uniza.sk/Priklady/vi deopriklady.htm

[3] CHRÁSKA, M. Metody pedagogického výzkumu. 2007, Grada 
Publishing, 265 s. ISBN 978-80247-1369-4

[4] JEŘÁBEK, O. - BÍLEK, M. Tvorby didaktických testů. Olomouc, 2010. ISBN 978-80-244-2494-1 [5] KOPÁČOVÁ, J. Kompetencie študentov učitel'stva pre primárne vzdelávanie na vyučovanie prírodovedy. In: Prídavková, A. - Klimovič, J. (eds.) Komplexnost' a integrita v predprimárnej, primárnej a špeciálnej edukácii. Prešov: Prešovská univerzita v Prešove, 2012, 643-647. ISBN 978-80-5550664-7

[6] KRIŠŤÁK, L. - NĚMEC, M. STEBILA, J. - DANIHELOVÁ, Z. Interactive P\&E Method in Teaching Physics at Secondary Schools. In: Journal of Technology and Information Education, Vol. 5, No. 1, 2013, pp. 42-49. ISSN 1803$537 \mathrm{X}$

[7] KRIŠŤÁK, L. - STEBILA, J. DANIHELOVÁ, Z. Experimental Support in Teaching Physics at Lower Secondary Schools. In: Scientia in educatione 4(1), 2013, pp. 3-18. ISSN 1804-7106

[8] MARKECHOVÁ, D. - STEHLÍKOVÁ, B. - TIRPÁKOVÁ, A. Štatistické metódy a ich aplikácie. Nitra 2011: Univerzita Konštantína Filozofa v Nitre, 534s. ISBN 98780-8094-807-8

[9] program STATISTICA (trial version), StatSoft, Inc. 2011.

[10] ROCHOVSKÁ, I. Formovanie prírodovednej gramotnosti študentov odboru predškolská a elemen- tárna pedagogika. Ružomberok: Verbum, 2012. 267 s. ISBN 97880-8084-859-0

[11] VALOVIČOVÁ, L. - JAKABOVÁ, S. a kol. Prírodovedné vzdelávanie formou projektového vyučovania. Nitra: FPV UKF v Nitre, 2012. 193 s. ISBN 978-80558-0149-0

Doc. PaedDr. Peter Hockicko, PhD.

RNDr. Gabriela Tarjányiová, PhD.

Katedra fyziky

Elektrotechnická fakulta ŽU

Univerzitná 8215/1

01026 Žilina, SR

Tel: +421 5132364

E-mail:

hockicko@fyzika.uniza.sk, tarjanyiova@fyzika.uniza.sk

www pracoviska:

http://fyzika.uniza.sk

Príloha (vstupný a výstupný test):

(1) Kameň padá vol'ným pádom do priepasti hlbokej $45 \mathrm{~m}$. Za aký čas dopadne na dno? Odpor vzduchu zanedbajte. (Kameň má pred dopadom rýchlost' $30 \mathrm{~m} / \mathrm{s}$ ).

(A) $3 \mathrm{~s}$ (B) $1,5 \mathrm{~s}$ (C) $4,5 \mathrm{~s}$ (D) $9 \mathrm{~s}$

(2) Graf na obrázku zodpovedá pohybu vlaku pred vjazdom do stanice. Aká bola vel'kost' zrýchlenia vlaku počas brzdenia?
(A) $30 / 8 \mathrm{~m} \cdot \mathrm{s}^{-2}$
(B) $30 / 12 \mathrm{~m} \cdot \mathrm{s}^{-2}$
(C) $30 / 10 \mathrm{~m} \cdot \mathrm{s}^{-2}$
(D) $40 / 12 \mathrm{~m} \cdot \mathrm{s}^{-2}$ 
(3) Akú dráhu prešiel vlak pri brzdení? (obrázok z predchádzajúceho príkladu)
(A) $200 \mathrm{~m}$
(B) $300 \mathrm{~m}$
(C) $400 \mathrm{~m}$
(D) $320 \mathrm{~m}$

(4) Brankár chytil loptu s hmotnost'ou $0,5 \mathrm{~kg}$, ktorá letela rýchlost'ou $18 \mathrm{~m} . \mathrm{s}^{-1}$. Akou priemernou silou pôsobil na loptu, ak ju zastavil za $0,06 \mathrm{~s}$ ?
(A) $150 \mathrm{~N}$
(B) $36 \mathrm{~N}$
(C) $300 \mathrm{~N}$
(D) $600 \mathrm{~N}$

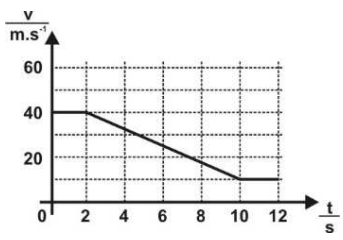

(5) Ktorá z uvedených jednotiek je jednotkou momentu zotrvačnosti? (A) $\mathrm{kg} \cdot \mathrm{m}^{2}$ (B) M.m (C) J (D) $\mathrm{m} \cdot \mathrm{s}^{-2}$

(6) Pohybová rovnica rotačného pohybu je vyjadrená vzt’ahom:
(A) $\mathrm{M}=\mathrm{J} . \varepsilon$
(B) $\mathrm{F}=\mathrm{m} \cdot \mathrm{a}$
(C) $\mathrm{L}=\mathrm{J} . \omega$
(D) $\mathrm{M}=\mathrm{F} \cdot \mathrm{r}$

(7) Auto sa pohybuje po ceste medzi bodmi $\mathrm{P}$ a Q rýchlost'ou, ktorá má konštantnú vel'kost' v. Na ceste sú dve zákruty, ktoré ležia na kružniciach $s$ polomermi $r_{B}=2 \cdot r_{A}$. Pre uhlové rýchlosti $\omega_{\mathrm{A}}$ a $\omega_{\mathrm{B}}$ platí:
(A) $\omega_{\mathrm{B}}=0,5 \cdot \omega_{\mathrm{A}}$
(B) $\omega_{\mathrm{B}}=0,25 \cdot \omega_{\mathrm{A}}$
(C) $\omega_{\mathrm{B}}=2 . \omega_{\mathrm{A}}$
(D) $\omega_{\mathrm{B}}=4 . \omega_{\mathrm{A}}$

(8) Od čoho nezávisí vel'kost’ trecej sily? Od
(A) dotykovej plochy
(B) hmotnosti telesa
(C) materiálu dotýkajúcich sa telies
(D) tiažového zrýchlenia

(9) Pozeráme sa na ručičkové hodinky v smere kolmom na ich ciferník. Aký smer má vektor momentu sily, ktorý spôsobuje pohyb minútovej ručičky hodín?

(A) Je kolmý na rovinu ciferníka a smeruje od nás.

(B) Je kolmý na rovinu ciferníka a smeruje ku nám.

(C) Leží $\mathrm{v}$ rovine ciferníka a je kolmý na ručičku.

(D) Má rovnaký smer ako ručička hodín.

(10) Bója tvaru gule s hmotnost'ou m leží v pokoji na hladine kvapaliny s hustotou $\rho$. Objem celej bóje je $\mathrm{V}$, objem ponorenej časti bóje je $\mathrm{V}_{1}$. Ktoré $\mathrm{z}$ nasledujúcich tvrdení o bóji je pravdivé?
(A) $\mathrm{V}_{1} \rho g=m g$
(B) $\mathrm{V} \rho g<\mathrm{mg}$
(C) $\mathrm{V}_{1} \rho g<\mathrm{mg}$
(D) $\left(\mathrm{V}+\mathrm{V}_{1}\right) \rho \mathrm{g}<\mathrm{mg}$

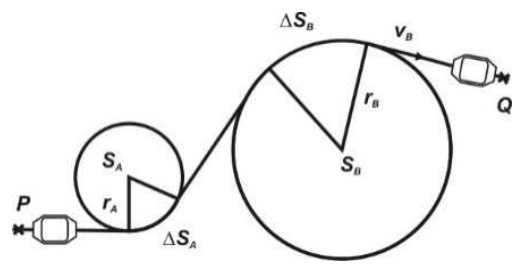


(11) Voda priteká rýchlost’ou $\mathrm{v}$ potrubím $\mathrm{s}$ priemerom d do rozšíreného miesta, ktoré má priemer 4d. Akou rýchlost'ou bude voda pretekat rozšíreným miestom?
(A) $\mathrm{v} / 16(\mathrm{~B}) 4 \mathrm{v}$
(C) $16 \mathrm{v}(\mathrm{D}) \mathrm{v} / 4$

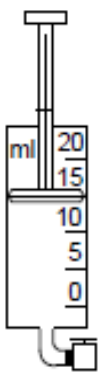

(12) Ako sa zmení vel'kost' tlaku v uzavretej trubici $\mathrm{s}$ prúdiacou kvapalinou, ked' sa prierez trubice zúži?
(A) zmenší sa
(B) zväčší sa
(C) nezmení sa
(D) je stále
nulový

(13) Pre koeficienty teplotnej rozt’ažnosti železa a betónu platí:
(A) sú porovnatel'né
(B) železo má rádovo nižší
(C) železo má rádovo vyšší
(D) sú úplne rovnaké

(14) Bubliny vzduchu stúpajúce $\mathrm{z}$ dna $\mathrm{k}$ hladine:
(A) sa zväčšujú
(B) sa zmenšujú
(C) nemenia vel'kost'
(D) nemenia vztlakovú silu, ktorá na ne pôsobí

(15) Akú prácu vykonal ideálny plyn počas jedného cyklu znázorneného na obrázku?

(16) Ventil, ku ktorému je pripojená injekčná striekačka, je uzavretý a pod piestom je tlak p. Ak posunieme piest na značku $5 \mathrm{ml}$, hodnota tlaku pod piestom bude približne rovná
(A) $3 p$
(B) $2 p$
(C) $p / 2$
(D) $p / 3$

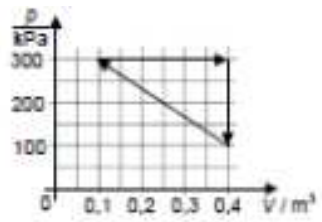

(17) Aká bude frekvencia oscilátora, ak sa jeho hmotnost' zmenší 9 krát? Jeho pôvodná frekvencia bola $81 \mathrm{~Hz}$.
(A) $243 \mathrm{~Hz}$
(B) $729 \mathrm{~Hz}$
(C) $9 \mathrm{~Hz}$
(D) $27 \mathrm{~Hz}$

(18) Závažie na špirálovej pružine kmitá na povrchu Zeme s frekvenciou $10 \mathrm{~Hz}$. Ako sa zmení frekvencia kmitov, ak by sme sústavu umiestnili na Mesiac?
(A) Nezmenila by sa.
(B) Zväčšila by sa.
(C) Závažie by vôbec nekmitalo.
(D) Zmenšila by sa.

(19) Na obrázku je znázornený priebeh výchylky kmitov v závislosti od času. Aká vel'ká je frekvencia uvedeného kmitavého pohybu?
(A) $0,25 \mathrm{~Hz}$
(B) $0,5 \mathrm{~Hz}$
(C) $2 \mathrm{~Hz}$
(D) $4 \mathrm{~Hz}$

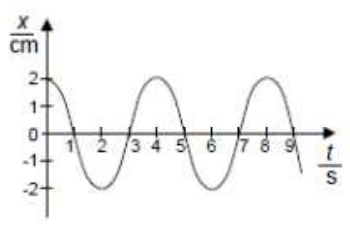


(20) Závažie s hmotnostou $1,2 \mathrm{~kg}$ je zavesené na pružine vedl'a stupnice $\mathrm{s}$ centimetrovými dielikmi (pozri obrázok). Približne aká je tuhost' tejto pružiny?
(A) $100 \mathrm{~N} \cdot \mathrm{m}^{-1}$
(B) $10 \mathrm{~N} \cdot \mathrm{m}^{-1}$
(C) $1 \mathrm{~N} \cdot \mathrm{m}^{-1}$
(D) $1000 \mathrm{~N} \cdot \mathrm{m}^{-1}$

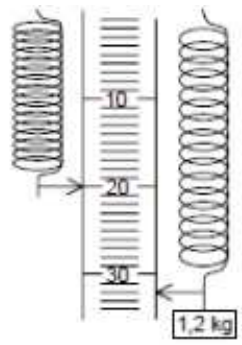
(A) $30 \mathrm{~kJ}$ (B) $60 \mathrm{~kJ}$
(C) $90 \mathrm{~kJ}$ (D) $120 \mathrm{~kJ}$ 